OPEN ACCESS

Edited by:

Vicky Karkou,

Edge Hill University, United Kingdom

Reviewed by:

Rory Allen,

Goldsmiths University of London,

United Kingdom

Ceymi Doenyas,

Koç University, Turkey

*Correspondence:

Einat Shuper Engelhard

Einat.Shuper@gmail.com

tThese authors have contributed equally to this work

Specialty section: This article was submitted to Psychology for Clinical Settings, a section of the journal

Frontiers in Psychology

Received: 21 October 2020

Accepted: 07 January 2021

Published: 18 February 2021

Citation:

Shuper Engelhard E and Vulcan M (2021) The Potential Benefits of Dance

Movement Therapy in Improving

Couple Relations of Individuals

Diagnosed With Autism Spectrum

Disorder-A Review.

Front. Psychol. 12:619936

doi: $10.3389 /$ fpsyg.2021.619936

\section{The Potential Benefits of Dance Movement Therapy in Improving Couple Relations of Individuals Diagnosed With Autism Spectrum Disorder-A Review}

\author{
Einat Shuper Engelhard ${ }^{1,2 * t}$ and Maya Vulcan ${ }^{1,2 t}$ \\ ${ }^{1}$ Faculty of Humanities and Social Sciences, Graduate School of Creative Art Therapies, Kibbutzim College of Education, \\ Tel Aviv, Israel, ${ }^{2}$ Faculty of Social Welfare and Health Sciences, Graduate School of Creative Art Therapies, Emili Sagol \\ Creative Arts Therapies Research Center, University of Haifa, Haifa, Israel
}

A review of current literature indicates that adults diagnosed with autism spectrum disorder (ASD) feel the need for intimate and sexual relationships and maintain such relationships despite and alongside their difficulties in emotional communication, social interactions, reciprocity, and verbal and non-verbal expression. This understanding calls for the development of intervention programs designed to support the specific needs and address the problems of couples where one partner is diagnosed with ASD. In view of the relevance and significant part played by body and movement in emotional development and psychotherapy, the present article offers a review of studies examining the contribution of dance movement therapy to both the quality of life and functioning of adults with ASD and therapeutic processes in couple therapy. This review aims to establish an infrastructure for the construction of intervention programs and for future studies designed to enhance the quality of life and independence of adults with ASD.

Keywords: autism spectrum disorder, couple therapy, dance movement therapy, dance movement therapy for couples, mirroring

The development of adult intimate relationships and the transition into couplehood are part of most people's life cycles, but these transitions become very challenging for individuals diagnosed with autism spectrum disorder (ASD) in as much as social interactions, emotional communication, and reciprocity, which are essential for interpersonal relationships (Le et al., 2010), are made more difficult due to the condition itself (Orsmond et al., 2004).

Research on couple therapy for adults diagnosed with ASD is in its infancy, and the core issues of the studies relate to the need for a better understanding of the unique aspects of intimacy and sexuality for these clients. Studies have examined the prevalence of marital relationships, reporting that $16 \%$ of individuals diagnosed with ASD get married (Tani et al., 2012). However, the specific difficulties entailed in the condition are an obstacle to the maintenance of a steady, long-term relationship, and significant support is needed to assist the development of these relationships and, in particular, in preserving them (Seltzer et al., 2004; Schöttle et al., 2017; Strunz et al., 2017; Dembosky, 2020).

Current research also explores the experience of typically developed (TD) individuals who are married to partners with ASD. Women married to partners with ASD describe their subjective 
experience of struggling and loneliness, which all-too-often lead to crises after marriage (Deguchi and Asakura, 2018), and the most problematic areas involve issues of affective communication, problem-solving communication, and quarreling (Roy and Dillo, 2017). Another complexity entailed in these relationships relates to the existence of social stigmas that partners may experience (Naoko et al., 2020).

A recent study which examined the perceptions of adults with and without ASD regarding intimacy found that, among the two groups, intimacy included communication, sharing and similarity, respect and safety for self and other, and working on the relationship. Barriers for both groups included intraand interpersonal conflicts; participants with ASD specifically highlighted uncertainty about relationships and communication, feeling that they did not have the required knowledge and skills. These findings suggest that individuals with ASD and TD individuals have similar notions of intimacy, yet they have different challenges in experiencing it (Sala et al., 2020).

An additional study (Cheak-Zamora et al., 2019) explored the sex and relationship experiences of 27 adults with ASD. The study found that the participants craved a relationship, but only few reported having partners. Among those that did, their actual relationships rarely met ideals. All of the participants expressed the need for tutoring and coaching that cover basic intimacy topics. These studies point to gaps between the desired and the actual life in the realm of intimacy and sexuality for adults with ASD. This gap highlights the need for further studies which would examine specifically tailored intervention programs intended to provide support for marital and sexual issues with this client population.

In spite of the recognition of the particular difficulties described above, the literature survey indicated that there is a distinctive lack of empirical studies that examine interventions for improving couple relationships in individuals with ASD. It is possible that one of the reasons for this lack is the fundamental question as to the efficacy of exclusively verbal work (Koegel et al., 2009; Anderberg et al., 2017) in as much as the clients' communication issues may pose significant problems for reciprocal verbal engagement and emotional reciprocity (Naber et al., 2008; Baron-Cohen, 2010; Eigsti et al., 2011; Vulcan, 2016).

At this point, in view of these lacunae, the manifested need at the clinical level, and the critical role of the body in understanding the complexity of an adult with ASD, we propose to take a step toward addressing these issues by offering a review of studies examining the advantages of dance movement therapy (DMT) to both the quality of life of adults with ASD and processes of couple therapy.We suggest that a specific focus on these two lines of research into ostensibly different "bodies of knowledge," as offered in this review, constitutes a step toward a research protocol and effective clinical interventions that would support the formation and maintenance of intimate relationships of adults with ASD.

This review was conducted in accordance with the PRISMA Checklist (PRISMA, 2015). The following three criteria were used to select the research studies for this review: (a) use of specific key terms ("DMT," "Couple Therapy", "Autism Spectrum Disorder," "Asperger's Disorder/syndrome," and "Pervasive Developmental
Disorder"); (b) publications in international evidence-based English academic journals between 1980 and 2020, and (c) adult individuals identified as having ASD, Asperger's, or pervasive developmental disorder who were involved in DMT and adult individuals in a romantic relationship who took part in DMTC. The following electronic databases were used to conduct this research study: Medline, Pubmed, Cinahl, and Springer Link.

\section{ASD AND DMT}

DMT is based on the assumption that pre-verbal, pre-mentalized bodily memories play an important role in relationships and influence our intimate experience (Shuper Engelhard, 2019b,c,d,e). DMT fosters embodied experiences through bodybased interventions and movement, and words are used to increase self-recognition, self-other distinction, and selfawareness on a bodily level, which positively influence social understanding (Fuchs and Koch, 2014; Koch et al., 2015). Moreover, it has been shown that moving between actions or inner felt experiences and their verbal expressions and practicing these transitions increase the ability to communicate feelings, needs, and emotions (Devereaux, 2012).

DMT interventions include various types of non-verbal mirroring, reflection, use of rhythm, regulatory movement, and movement synchrony-all of which are broadly aimed at helping the client practice relationship skills to attain bodily attunement and empathy and to get acquainted with feelings and needs through the experience of synchronization (McGarry and Russo, 2011; Behrends et al., 2012).

Through the body, DMT addresses issues of emotion and cognition, applying empathic reflection via mirroring of the client's movements in order to form a relationship and enhance emotional understanding of self and other. The assumption underlying this therapeutic modality is that these basic, nonverbal interactions, within the safe and secure clinical setting, serve as a bridge for the formation of relationships and for the enhancement of communicative functioning in relationships outside the clinic in day-to-day context (Baron-Cohen and Wheelwright, 2004).

Studies examining the contribution of DMT with adults diagnosed with ASD have found that their ability to synchronize in open and free movement is limited compared to TD but not completely impaired, and researchers recommend using these tools to develop the social skills of empathic tendency, emotional recognition, and affective engagement (Brezis et al., 2017). Studies, respectively, show that the practice of mirroring, synchronization, rhythm, and reciprocity in movement contributes to social involvement, body awareness (DeJesus et al., 2020), emotional engagement, rapport, and intersubjective communication (Delafield-Butt et al., 2020), emotional empathy (Mastrominico et al., 2018), and the expression of emotions (Takahashi et al., 2019). Several studies in the field describe the effect of 1-h intervention per 6 weeks on regulation, imitation, and interaction (Mateos-Moreno and Atencia-Doña, 2013), for 7 weeks on improvement in psychological well-being, body awareness, self-other awareness, 
and social skills (Koch et al., 2015), for 8 weeks on the ability to form relationships (Edwards, 2015), and for 10 weeks on emotional expression (Hildebrandt et al., 2016), body image (Koch et al., 2016), and cognitive empathy (Koehne et al., 2016b). The interventions in all these studies are based on movement reflection, followed by a verbal discourse that allows the experience to be processed and communicated from the body to the here-and-now. The researchers in all of these studies emphasize the contribution of the practice of empathy in movement (through synchronizing and joining others) to emotional and social understanding (Table 1).

Following this, our review aims to examine the theoretical basis for a DMT model that could hopefully assist adults with ASD in their intimate romantic relationships by enhancing satisfaction, working toward stabilizing the partnership, and extending its duration.

\section{DMT FOR COUPLES}

DMT for couples (DMT-C) focuses on body sensations and movement and lays the ground for symbolic discourse, insight, and processing of psychic materials that influence the couple's relationship (Wagner and Hurst, 2018). The majority of the literature on the subject is based on case studies offering movement experiences combined with verbal discourse during the couple therapy session (Table 2).

Research in the field of DMT-C found that the experience of expressive movement, synchronization, and mutual attunement through movement had a positive impact on the perceived relationships, an increase of kinesthetic empathy, and an improvement of the participants' ability to attune in relation to their partners' needs (Kim et al., 2013). These skills are precisely those so essential in couple relationships (Le et al., 2010), which may be complex and difficult for adults diagnosed with ASD (Orsmond et al., 2004). Another study found that the imitation of a personal choreography, movement synchronization, and collaboration in resolving incidents of non-synchronization of movement resulted in higher marital satisfaction, more secure attachment, and higher empathy in the relationship (Pietrzak et al., 2017). Furthermore, couples reported experiences of movement with their hands (Wagner and Hurst, 2018), being led in space by their partner (Polo, 2010), mirroring and imitating movement (DeBoer, 2006; Patterson et al., 2012; Lacson, 2020), raised awareness of emotional content from the couples' daily lives, and the ability to understand the emotional needs of the partner. The interventions in the various studies range from $8 \mathrm{~h}$ (Kim et al., 2013) of practice to $12 \mathrm{~h}$ (Hawkes, 2003; Pietrzak et al., 2017) as similarly described above in DMT interventions with adults diagnosed with ASD.

In a recent research project, nine couples with TD participated in 12 sessions of DMT-C (Shuper Engelhard, 2018, 2019a,b,c,d,e; Shuper Engelhard and Vulcan, 2018; Vulcan and Shuper Engelhard, 2019). A total of $126 \mathrm{~h}$ of therapy were transcribed and coded. The session began with an invitation to observe the "spontaneous joint movement" (for example, the couple was invited to walk around the room while observing their personal pace and their dyadic pace). As the session continued, the "spontaneous joint movement" was expanded (for example, through the examination of different rhythms). This expansion was designed to meet diverse feelings and emotions evoked through different movement patterns of the partners. The following phase in the session included the "mirroring of movement," where each partner was invited to move like his/her partner. After each experience of movement, the therapist asked the couple to practice an inner observation of feelings, emotions, memories, and images that emerge after the movement experience. At the end of the session, the couple was invited to share with each other their movement experience in words.

This study found that the participants learned new verbal and non-verbal communication skills, and as a result, they experienced a sense of improved intimacy, and their relationship became more enjoyable. It was also found that the shared body experience helped the partners to increase mutual engagement, responsiveness, and attentiveness (Shuper Engelhard, 2019c). They each learned about the needs of the other, including which bodily experiences bring about a sense of security in the relationship (Shuper Engelhard, 2019d).

In all the studies described, the couples were without any formal diagnosis, except for a single study involving couples with borderline personality disorder (Pietrzak et al., 2017). The review did not find any studies on DMT for adults diagnosed with ASD who are involved in a romantic relationship. All of the interventions offered for DMT with couples are similar to the type of interventions recommended for adults diagnosed with ASD (e.g., synchronization, mirroring, imitation, etc.) in order to enhance social skills and the ability to recognize the other's emotional expression and feelings. Moreover, both studies in DMT-C and studies of DMT for adults diagnosed with ASD suggest the combination of sensory and kinesthetic experience with verbal processing. In couple therapy, the partners reported that their communication improves as the somatic and kinetic information is translated into verbal discourse (Vulcan and Shuper Engelhard, 2019). This is compatible with Bird and Viding's model of empathy (Bird and Viding, 2014; FletcherWatson and Bird, 2020), as the contribution of verbalization of the sensory experiences among adults diagnosed with ASD (Hildebrandt et al., 2016) is important to the development of emotional cognition that should be based on learning the connections between emotional action and emotional experience (i.e., identifying the emotion through its expression). These insights reinforce the importance of an intervention that focuses on identifying the other's body gestures as a way to bring about more satisfying communication in the relationship.

\section{DMT-C FOR ASD}

We aim to offer this review as a springboard for the development of effective intervention models, which would enhance the ability of adults with ASD to form intimate relations. Further research that can validate the use of DMT-C for ASD is warranted, but based on this review, we would recommend a research plan which, we believe, is likely to generate important and 
TABLE 1 | Adults diagnosed with autism spectrum disorder and dance movement therapy.

\begin{tabular}{|c|c|c|c|c|c|c|c|}
\hline References & $\begin{array}{l}\text { Study } \\
\text { design }\end{array}$ & Objective & Sample & $\begin{array}{l}\text { Intervention } \\
\text { length }\end{array}$ & $\begin{array}{l}\text { Intervention } \\
\text { elements }\end{array}$ & Evaluation tools & Results and conclusions \\
\hline $\begin{array}{l}\text { Brezis et al. } \\
\text { (2017) }\end{array}$ & $\begin{array}{l}\text { Experimental } \\
\text { setup }\end{array}$ & $\begin{array}{l}\text { Examining } \\
\text { synchronization } \\
\text { during an } \\
\text { open-ended joint } \\
\text { improvization } \\
\text { paradigm - the } \\
\text { mirror game (MG), } \\
\text { aiming to assess } \\
\text { whether participants } \\
\text { with ASD are } \\
\text { capable of attaining } \\
\text { co-confidence and } \\
\text { whether their MG } \\
\text { performance relates } \\
\text { to broader motor } \\
\text { and social skills }\end{array}$ & $\begin{array}{l}\text { Thirty-four } \\
\text { participants with } \\
\text { high-functioning } \\
\text { ASD and } 38 \text { TD }\end{array}$ & $\begin{array}{l}\text { The } \\
\text { experimental } \\
\text { sessions lasted } \\
\text { for } 2-3 \mathrm{~h}\end{array}$ & $\begin{array}{l}\text { The Mirror Game } \\
\text { Procedure, including } \\
\text { the reaching task, } \\
\text { proprioception task, } \\
\text { repetitive motion task, } \\
\text { and following a moving } \\
\text { target task }\end{array}$ & $\begin{array}{l}\text { MG; the Revised } \\
\text { Neurological } \\
\text { Examination for } \\
\text { Subtle Signs } \\
\text { (PANESS); the Florida } \\
\text { Apraxia Battery, an } \\
\text { imitation battery } \\
\text { based on Fitzpatrick } \\
\text { et al. (2013); Toronto } \\
\text { Empathy } \\
\text { Questionnaire, TEQ; } \\
\text { Reading the Mind in } \\
\text { the Eyes, RMET; } \\
\text { Toronto Alexithymia } \\
\text { Scale, TAS. } \\
\text { Following the MG, } \\
\text { the participants } \\
\text { completed a } \\
\text { naturalistic } \\
\text { conversation task }\end{array}$ & $\begin{array}{l}\text { ASD participants can attain } \\
\text { moments of high motor } \\
\text { synchronization, even during an } \\
\text { open-ended task. Joint } \\
\text { synchronization was not } \\
\text { inexistent, but simply reduced, } \\
\text { in individuals with ASD, and } \\
\text { their existing synchronization } \\
\text { skills may be further harnessed } \\
\text { in clinical settings to support } \\
\text { their personal expression and } \\
\text { social rapport }\end{array}$ \\
\hline $\begin{array}{l}\text { DeJesus et al. } \\
(2020)\end{array}$ & $\begin{array}{l}\text { Systematic } \\
\text { review }\end{array}$ & $\begin{array}{l}\text { Identifying how } \\
\text { dance promotes } \\
\text { positive benefits for } \\
\text { the negative } \\
\text { symptoms in ASD }\end{array}$ & $\begin{array}{l}\text { Five studies } \\
\text { fulfilled the } \\
\text { inclusion criteria }\end{array}$ & - & $\begin{array}{l}\text { Analysis of article titles, } \\
\text { reading summaries of } \\
\text { articles that had been } \\
\text { identified, reading the } \\
\text { entire article, analyzing } \\
\text { article references from } \\
\text { those that had been } \\
\text { read in their entirety }\end{array}$ & $\begin{array}{l}\text { Research question } \\
\text { based on the PICO } \\
\text { strategy. Five } \\
\text { databases were } \\
\text { used: the National } \\
\text { Library of Medicine } \\
\text { (MEDLINE-PubMed), } \\
\text { Science Direct, Web } \\
\text { of Science, Scopus, } \\
\text { and PsyclNFO } \\
\text { (APA-American } \\
\text { Psychological } \\
\text { Association) }\end{array}$ & $\begin{array}{l}\text { Dance practice can promote a } \\
\text { beneficial effect on the negative } \\
\text { symptoms of individuals with } \\
\text { ASD in daily life as well as } \\
\text { positively influence } \\
\text { biopsychosocial aspects. It } \\
\text { contributes to body awareness } \\
\text { and social involvement using } \\
\text { techniques like mirroring, } \\
\text { synchronization, rhythm, and } \\
\text { reciprocity }\end{array}$ \\
\hline $\begin{array}{l}\text { Edwards } \\
\text { (2015) }\end{array}$ & $\begin{array}{l}\text { Qualitative, } \\
\text { reflective } \\
\text { participant } \\
\text { observation } \\
\text { (case study) } \\
\text { methodology } \\
\text { within a } \\
\text { realism } \\
\text { perspective }\end{array}$ & $\begin{array}{l}\text { Exploring sensory } \\
\text { experiences of } \\
\text { adults with autism } \\
\text { and to find out how } \\
\text { they form } \\
\text { relationships, } \\
\text { including attachment } \\
\text { behaviors, within a } \\
\text { DMT group }\end{array}$ & $\begin{array}{l}\text { Four adults } \\
\text { diagnosed with } \\
\text { autism }\end{array}$ & $\begin{array}{l}\text { Eight-week } \\
\text { period (the } \\
\text { participants } \\
\text { attended DMT } \\
\text { sessions for } 12 \\
\text { months prior to } \\
\text { the research } \\
\text { period) }\end{array}$ & Not described & $\begin{array}{l}\text { (1) Movement } \\
\text { observations by } \\
\text { therapists, (2) verbal } \\
\text { feedback from the } \\
\text { participants was } \\
\text { noted at the end of } \\
\text { each session, and (3) } \\
\text { the therapists' } \\
\text { reflective journals }\end{array}$ & $\begin{array}{l}\text { Accommodating and adjusting } \\
\text { to sensory differences } \\
\text { influenced how the participants } \\
\text { formed relationships, which } \\
\text { suggests that DMT was a } \\
\text { beneficial intervention for them }\end{array}$ \\
\hline $\begin{array}{l}\text { Hildebrandt } \\
\text { et al. (2016) }\end{array}$ & $\begin{array}{l}\text { Cohort study } \\
\text { RCT }\end{array}$ & $\begin{array}{l}\text { Examining the effect } \\
\text { of movement } \\
\text { therapy intervention } \\
\text { (based on DMT) on } \\
\text { negative symptoms } \\
\text { (NS) in participants } \\
\text { with ASD }\end{array}$ & $\begin{array}{l}\text { Seventy-eight } \\
\text { individuals with } \\
\text { ASD: } 55 \text { in the } \\
\text { intervention } \\
\text { group and } 23 \text { in } \\
\text { the control group }\end{array}$ & $\begin{array}{l}\text { Ten weekly } \\
\text { sessions with a } \\
\text { duration of } \\
60 \text { min }\end{array}$ & $\begin{array}{l}\text { Manualized DMT } \\
\text { intervention. Each } \\
\text { session consisted of } \\
\text { three mirroring } \\
\text { exercises and one } \\
\text { verbal processing } \\
\text { element. The control } \\
\text { group received no } \\
\text { intervention }\end{array}$ & $\begin{array}{l}\text { Scale for the } \\
\text { Assessment of } \\
\text { Negative Symptoms } \\
\text { (SANS) }\end{array}$ & $\begin{array}{l}\text { The study highlighted the } \\
\text { influence of dance practice on } \\
\text { negative symptoms, including } \\
\text { emotional expression, with an } \\
\text { interaction effect at the } \\
\text { significance level of } 0.1 \text {, } \\
\text { indicating symptom reduction in } \\
\text { the dance group }\left[F_{(1.4)}=2.99 \text {, }\right. \\
p=0.09] \text {. The effect sizes were } \\
\text { small but clinically meaningful, } \\
\text { and the resulting patterns were } \\
\text { in accordance with theoretical } \\
\text { expectations. }\end{array}$ \\
\hline
\end{tabular}


TABLE 1 | Continued

\begin{tabular}{|c|c|c|c|c|}
\hline References & $\begin{array}{l}\text { Study } \\
\text { design }\end{array}$ & Objective & Sample & $\begin{array}{l}\text { Intervention } \\
\text { length }\end{array}$ \\
\hline $\begin{array}{l}\text { Koch et al. } \\
\text { (2015) }\end{array}$ & $\begin{array}{l}\text { Cohort study, } \\
\text { clinical trial }\end{array}$ & $\begin{array}{l}\text { To examine the } \\
\text { effectiveness of DMT } \\
\text { intervention based } \\
\text { on mirroring in } \\
\text { movement with ASD } \\
\text { in increasing body } \\
\text { awareness, social } \\
\text { skills, self-other } \\
\text { distinction, empathy, } \\
\text { and well-being }\end{array}$ & $\begin{array}{l}\text { Thirty-one young } \\
\text { adults } \\
\text { diagnosed with } \\
\text { ASD: } 16 \text { in the } \\
\text { intervention } \\
\text { group and } 15 \text { in } \\
\text { the control group }\end{array}$ & $\begin{array}{l}\text { Seven weeks of } \\
\text { hourly sessions } \\
\text { once a week }\end{array}$ \\
\hline
\end{tabular}

$\begin{array}{ll}\text { Koch et al. } & \text { Intervention } \\ \text { (2016). } & \text { research }\end{array}$

Koehne et al. Intervention(2016a)
Investigating the Ten young adults Ten weekly effects of DMT on with ASD body image in autism sessions of D received no intervention

DMT intervention based on therapeutic mirroring and verbal processing
Body-imagesculpture test, a projective test (KST)
(1) Pretest and

treatment-manualized posttest

MuT intervention of Questionnairesmirroring exercises and Heidelberger State Inventory,

Questionnaire of Movement Therapy; (2) self-other awareness self-constructed scale; short form of the EES. FBT

subscale of social skills; observations of mirroring modalities through the concept of co- and self-regulation from Eberhard-Kaechele (2009, 2012); qualitative expressive measures (painting a picture or writing a short poem)

\section{controlled} parallel-group clinical trial (proof-ofconcept study)
Establishing the efficacy of imitationand synchronizationbased DMT intervention (SIDMI) in fostering emotion inference and empathic feelings with high-functioning adults with $A S D$
Fifty-five adults Ten weeks of a DMT interventions

with ASD: 29 in DMT intervention focused on

the intervention administered in interpersonal group and 26 in 10 90-min the control group sessions over the course of 3 months movement imitation and synchronization (SI-DMI) and a control movement intervention focusing on individual motor coordination (CMI)
The effect sizes indicate a moderate effect for group and a small effect for the interaction term

DMT can be effective and feasible for the treatment of individuals with ASD, causing improvement in psychologica well-being, body awareness, self-other awareness, and social skills compared with the control group $\left[F_{(1.27)}=2.95\right.$, $p=0.04, d=0.63]$. Outcomes improved significantly in the expected direction with medium to large effects (effect sizes of 0.61-0.91)

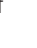

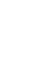


TABLE 1 | Continued

\begin{tabular}{|c|c|c|c|c|c|c|c|}
\hline References & $\begin{array}{l}\text { Study } \\
\text { design }\end{array}$ & Objective & Sample & $\begin{array}{l}\text { Intervention } \\
\text { length }\end{array}$ & $\begin{array}{l}\text { Intervention } \\
\text { elements }\end{array}$ & Evaluation tools & Results and conclusions \\
\hline & & & & & & & $\begin{array}{l}\text { Interaction effects related to } \\
\text { social reciprocity were also } \\
\text { promoted by } \\
\text { imitation/synchronization } \\
(p<0.001, d=1.27) \text { and } \\
\text { reciprocity/dialogue }(p=0.04, d \\
=1.25) \text {, respectively. Those } \\
\text { treated with SI-DMl showed a } \\
\text { significantly larger improvement } \\
\text { in emotion inference than those } \\
\text { treated with CMI. SI-DMl } \\
\text { increased synchronization skills } \\
\text { and imitation tendencies, as } \\
\text { well as whole-body } \\
\text { imitation/synchronization and } \\
\text { movement reciprocity/dialogue, } \\
\text { compared to CMI }\end{array}$ \\
\hline $\begin{array}{l}\text { Mastrominico } \\
\text { et al. (2018) }\end{array}$ & $\begin{array}{l}\text { Cohort } \\
\text { study-RCT }\end{array}$ & $\begin{array}{l}\text { Examining the } \\
\text { effects of DMT on } \\
\text { empathy for adults } \\
\text { with ASD }\end{array}$ & $\begin{array}{l}\text { Fifty-seven } \\
\text { individuals with } \\
\text { ASD: } 35 \text { in the } \\
\text { intervention } \\
\text { group and } 22 \text { in } \\
\text { the control group }\end{array}$ & $\begin{array}{l}\text { Ten DMT } \\
\text { sessions once a } \\
\text { week }\end{array}$ & $\begin{array}{l}\text { Manualized form of } \\
\text { DMT. }\end{array}$ & $\begin{array}{l}\text { Empathy, measured } \\
\text { with the Cognitive } \\
\text { and Emotional } \\
\text { Empathy } \\
\text { Questionnaire } \\
\text { (CEEQ); observational } \\
\text { measures such as } \\
\text { the SANS-scale for } \\
\text { negative symptoms; } \\
\text { the subscale } \\
\text { Empathic Concern of } \\
\text { the Interpersonal } \\
\text { Reactivity Index (IRI) }\end{array}$ & $\begin{array}{l}\text { Mirroring interventions had an } \\
\text { effect on empathy, relationships, } \\
\text { and perception of the feelings of } \\
\text { others as well as psychological } \\
\text { health. The main effect of time } \\
\text { compared with control group } \\
\text { yield findings for emotional } \\
\text { empathy }\left[F_{(1,55)}=12.55, p=\right. \\
\left.0.001, \eta^{2}=0.19\right) \text { and its } \\
\text { subscales mirroring }\left[F_{(1,55)}=\right. \\
\left.\text { 9.22, } p=0.004, \eta^{2}=0.14\right) \text { and } \\
\text { empathic concern }\left[F_{(1,55)}=\right. \\
\left.4.99, p=0.030, \eta^{2}=0.08\right]\end{array}$ \\
\hline $\begin{array}{l}\text { Mateos- } \\
\text { Moreno and } \\
\text { Atencia- } \\
\text { Doña, } \\
2013\end{array}$ & $\begin{array}{l}\text { Experimental } \\
\text { study }\end{array}$ & $\begin{array}{l}\text { Assessing the } \\
\text { effectiveness of DMT } \\
\text { and music therapy } \\
\text { (MT) procedures on } \\
\text { adults with severe } \\
\text { autism }\end{array}$ & $\begin{array}{l}\text { Sixteen } \\
\text { participants }\end{array}$ & $\begin{array}{l}\text { Thirty-six } 1-h \\
\text { sessions during } \\
17 \text { weeks }\end{array}$ & $\begin{array}{l}\text { A number of varied MT } \\
\text { and DMT activities in } \\
\text { each session. The core } \\
\text { of each session } \\
\text { consisted of dance, } \\
\text { instrumental practice, } \\
\text { singing, and } \\
\text { observation/mimicking } \\
\text { of movement }\end{array}$ & $\begin{array}{l}\text { Revised Clinical Scale } \\
\text { for the Evaluation of } \\
\text { Autistic Behavior } \\
\text { (ECA-R). During the } \\
\text { treatment, eight } \\
\text { measurements were } \\
\text { taken (one every } 3 \\
\text { weeks) }\end{array}$ & $\begin{array}{l}\text { The observed power by partial } \\
\text { squared Eta was high } \\
(2=0.90, p<0.001) \text { in the } \\
\text { progression of measures in the } \\
\text { experimental group. }\end{array}$ \\
\hline
\end{tabular}


TABLE 1 | Continued

\begin{tabular}{|c|c|c|c|c|c|c|c|}
\hline References & $\begin{array}{l}\text { Study } \\
\text { design }\end{array}$ & Objective & Sample & $\begin{array}{l}\text { Intervention } \\
\text { length }\end{array}$ & $\begin{array}{l}\text { Intervention } \\
\text { elements }\end{array}$ & Evaluation tools & Results and conclusions \\
\hline & & & & & & & $\begin{array}{l}\text { The value of partial squared } \\
\text { omega } \omega^{2}=0.69 \text { estimates an } \\
\text { equally high effect size (Cohen, } \\
\text { 1988) of the treatment if } \\
\text { systematically applied to the } \\
\text { severely affected adult autistic } \\
\text { population. The observed } \\
\text { power (Cohen's } d=1.18 \text {, } \\
r=0.51 \text { ) suggests a moderate } \\
\text { effect size (Cohen, 1988) on the } \\
\text { interaction disorder. }\end{array}$ \\
\hline & & & & & & & $\begin{array}{l}\text { The observed power (Cohen's } \\
d=1.88, r=0.68 \text { ) suggests an } \\
\text { elevated effect size (Cohen, } \\
\text { 1988) on the instinct disorder. }\end{array}$ \\
\hline & & & & & & & $\begin{array}{l}\text { The study provides preliminary } \\
\text { evidence for the high benefits of } \\
\text { jointly using MT and DMT with } \\
\text { severely affected autistic adults }\end{array}$ \\
\hline $\begin{array}{l}\text { Takahashi } \\
\text { et al. (2019) }\end{array}$ & $\begin{array}{l}\text { Systematic } \\
\text { review }\end{array}$ & $\begin{array}{l}\text { To verify the quality } \\
\text { of DMT and ASD } \\
\text { studies using } \\
\text { Preferred Reporting } \\
\text { Items for Systematic } \\
\text { Reviews and } \\
\text { Meta-Analyses } \\
\text { (PRISMA) guidelines } \\
\text { and to evaluate the } \\
\text { effectiveness of DMT } \\
\text { interventions for } \\
\text { individuals with ASD }\end{array}$ & Seven studies & Not described & $\begin{array}{l}\text { The criteria were (a) use } \\
\text { of specific key terms, } \\
\text { (b) publications in } \\
\text { international } \\
\text { evidence-based } \\
\text { English academic } \\
\text { journals between } 1970 \\
\text { and } 2018 \text {, (c) the } \\
\text { specific words were } \\
\text { used in the papers' } \\
\text { abstract, and (d) } \\
\text { individuals involved in } \\
\text { DMT were identified as } \\
\text { having ASD, } \\
\text { Asperger's, or PDD }\end{array}$ & $\begin{array}{l}\text { Keyword analyses of } \\
\text { four electronic } \\
\text { databases-Medline, } \\
\text { Pubmed, Cinahl, and } \\
\text { Springer Link }\end{array}$ & $\begin{array}{l}\text { Imitation (mirroring) interventions } \\
\text { helped individuals with ASD } \\
\text { improve their social skills. DMT } \\
\text { treatment will help mitigate the } \\
\text { difficulty of sociality in ASD and } \\
\text { is an effective preventive or } \\
\text { treatment measure for } \\
\text { improving social skills }\end{array}$ \\
\hline $\begin{array}{l}\text { Wadsworth } \\
\text { and Hackett } \\
\text { (2014) }\end{array}$ & $\begin{array}{l}\text { An } \\
\text { observational } \\
\text { single-case } \\
\text { study and a } \\
\text { practice- } \\
\text { based } \\
\text { research } \\
\text { approach }\end{array}$ & $\begin{array}{l}\text { Introducing a } \\
\text { structured narrative } \\
\text { approach in the form } \\
\text { of the six-part story } \\
\text { within DMT with an } \\
\text { adult with ASD }\end{array}$ & One participant & $\begin{array}{l}\text { Seven DMT } \\
\text { sessions lasting } \\
45 \mathrm{~min}\end{array}$ & $\begin{array}{l}\text { A consistent format } \\
\text { including a warm-up, } \\
\text { mirroring, a "six-part } \\
\text { story," and relaxation } \\
\text { techniques }\end{array}$ & $\begin{array}{l}\text { The BASIC-Ph; the } \\
\text { creative arts } \\
\text { therapies session } \\
\text { rating scale } \\
\text { (CAT-SRS); Picture } \\
\text { Communication } \\
\text { Symbols TM } \\
\text { Boardmaker program }\end{array}$ & $\begin{array}{l}\text { The study results indicate that } \\
\text { DMT practice can incorporate } \\
\text { structured narrative approaches } \\
\text { in work with adults with ASD }\end{array}$ \\
\hline $\begin{array}{l}\text { Zapata- } \\
\text { Fonseca et al. } \\
\text { (2019) }\end{array}$ & $\begin{array}{l}\text { A quantitative } \\
\text { description }\end{array}$ & $\begin{array}{l}\text { Providing a } \\
\text { quantifiable link } \\
\text { between individual } \\
\text { motor movement } \\
\text { markers as potential } \\
\text { diagnostic tools for } \\
\text { ASD and social } \\
\text { interaction deficits of } \\
\text { ASD, which are } \\
\text { currently the two } \\
\text { main diagnostic } \\
\text { criteria }\end{array}$ & $\begin{array}{l}\text { Ten dyads of } \\
\text { adult } \\
\text { participants }\end{array}$ & Not described & $\begin{array}{l}\text { Interpersonal } \\
\text { coordination } \\
\text { complexity matching } \\
(\mathrm{CM}) \text {, individual } \\
\text { movement profiles, } \\
\text { multi-scale movement } \\
\text { variability }\end{array}$ & $\begin{array}{l}\text { The time series of } \\
\text { embodied interaction } \\
\text { was recorded by } \\
\text { means of a } \\
\text { minimalistic } \\
\text { human-computer } \\
\text { interface paradigm } \\
\text { that has become } \\
\text { known as the } \\
\text { "perceptual crossing } \\
\text { experiment" (PCE) }\end{array}$ & $\begin{array}{l}\text { An overall mutual coordination } \\
\text { was reached at the dyad level, } \\
\text { even in this highly constrained, } \\
\text { minimal environment. Research } \\
\text { supports the usage of } \\
\text { computer-mediated and tactile } \\
\text { interactions for understanding } \\
\text { the relationship between } \\
\text { movement-based coordination } \\
\text { and social engagement in } \\
\text { patients with ASD }\end{array}$ \\
\hline
\end{tabular}

novel clinical information and help to reduce social isolation in adults with ASD. The proposed intervention protocol focuses on mirroring, synchronization, and mutual coordination. A DMT-C session for ASD should consist of a warm-up phase, followed by movement experiences and a closing verbal part. This protocol should take place for at least 6 weeks, with two 1-h sessions each week, as all of these were found to contribute to both couple therapy and interventions for adults with ASD. 
TABLE 2 | Dance movement therapy for couples.

\begin{tabular}{|c|c|c|c|c|c|c|c|}
\hline References $^{a}$ & $\begin{array}{l}\text { Study } \\
\text { design }\end{array}$ & Objective & Sample & $\begin{array}{l}\text { Intervention } \\
\text { length }\end{array}$ & Intervention elements & Evaluation tools & Results/conclusions \\
\hline $\begin{array}{l}\text { Cunningham } \\
\text { (2014) }\end{array}$ & $\begin{array}{l}\text { Mixed- } \\
\text { method case } \\
\text { study; no } \\
\text { control group }\end{array}$ & $\begin{array}{l}\text { Reflecting on the } \\
\text { positive impact DMT } \\
\text { has on emotional } \\
\text { stress factors with } \\
\text { couples experiencing } \\
\text { infertility }\end{array}$ & $\begin{array}{l}\text { Two } \\
\text { Counselors }\end{array}$ & $\begin{array}{l}\text { No } \\
\text { description }\end{array}$ & No description & $\begin{array}{l}\text { (1) Quality of life } \\
\text { (QoL) } \\
\text { questionnaire; (2) } \\
\text { qualitative } \\
\text { questionnaire }\end{array}$ & $\begin{array}{l}\text { DMT allows the couple to } \\
\text { process their traumatic } \\
\text { experience, re-imagine } \\
\text { themselves, and move } \\
\text { toward the actualization } \\
\text { of a new unmet potential }\end{array}$ \\
\hline $\begin{array}{l}\text { Hawkes } \\
\text { (2003) }\end{array}$ & Clinical report & $\begin{array}{l}\text { Describing the use of } \\
\text { partner dance as a } \\
\text { "container" for the } \\
\text { experience and } \\
\text { feelings of participants } \\
\text { in a group }\end{array}$ & $\begin{array}{l}\text { No } \\
\text { description }\end{array}$ & $\begin{array}{l}\text { Weekend } \\
\text { workshops, } \\
12 \text { h over } 2 \\
\text { days }\end{array}$ & $\begin{array}{l}\text { Facilitating awareness of } \\
\text { and experimenting with } \\
\text { posture, how } \\
\text { participants move and } \\
\text { sense their bodies, and } \\
\text { how they relate to others } \\
\text { through their bodies }\end{array}$ & $\begin{array}{l}\text { No evaluation } \\
\text { tools }\end{array}$ & $\begin{array}{l}\text { Dancing with a partner } \\
\text { particularly opens up } \\
\text { issues concerning the } \\
\text { other }\end{array}$ \\
\hline Kierr (2011) & $\begin{array}{l}\text { Theoretical } \\
\text { model }\end{array}$ & $\begin{array}{l}\text { Identifying techniques } \\
\text { which are designed to } \\
\text { develop healthy } \\
\text { sexuality }\end{array}$ & - & - & $\begin{array}{l}\text { Here-and-now } \\
\text { exercises, guided } \\
\text { imagery, assertiveness } \\
\text { training, sensory } \\
\text { integration activities }\end{array}$ & - & - \\
\hline $\begin{array}{l}\text { Kim et al. } \\
\text { (2013) }\end{array}$ & $\begin{array}{l}\text { Qualitative } \\
\text { research } \\
\text { method }\end{array}$ & $\begin{array}{l}\text { To configure and apply } \\
\text { the kinesthetic } \\
\text { empathy program and } \\
\text { to assess its } \\
\text { effectiveness for } \\
\text { married couples in } \\
\text { conflict }\end{array}$ & $\begin{array}{l}\text { Three } \\
\text { couples }\end{array}$ & $\begin{array}{l}\text { Four 2-h } \\
\text { sessions }\end{array}$ & $\begin{array}{l}\text { Body } \\
\text { concept-focusing on } \\
\text { breath awareness. } \\
\text { Space } \\
\text { concept-focusing on } \\
\text { personal space } \\
\text { awareness. Effort } \\
\text { concept-focusing on } \\
\text { care-giving daily } \\
\text { movement. Relationship } \\
\text { concept-focusing on } \\
\text { sharing most } \\
\text { memorable moment of } \\
\text { martial life }\end{array}$ & $\begin{array}{l}\text { (1) Focus group } \\
\text { interview and (2) } \\
\text { semi-structured } \\
\text { and unstructured } \\
\text { questionnaire }\end{array}$ & $\begin{array}{l}\text { Expressive movement, } \\
\text { synchronization, and } \\
\text { mutual attunement } \\
\text { through movement had a } \\
\text { positive impact on the } \\
\text { perceived relationships, } \\
\text { an increase of kinesthetic } \\
\text { empathy, and an } \\
\text { improvement of the } \\
\text { participants' ability to } \\
\text { emotionally attune in } \\
\text { relation to their partners }\end{array}$ \\
\hline $\begin{array}{l}\text { Patterson } \\
\text { et al. (2012) }\end{array}$ & $\begin{array}{l}\text { Quantitative } \\
\text { research }\end{array}$ & $\begin{array}{l}\text { Identifying specific } \\
\text { nonverbal behaviors } \\
\text { associated with } \\
\text { different affective } \\
\text { states }\end{array}$ & $\begin{array}{l}\text { Thirty } \\
\text { partners }\end{array}$ & - & No description & $\begin{array}{l}\text { (1) Self-report } \\
\text { questionnaire, (2) } \\
\text { saliva samples, (3) } \\
\text { a video-recall } \\
\text { procedure rating } \\
\text { affect during two } \\
\text { conversations }\end{array}$ & $\begin{array}{l}\text { Body movement in } \\
\text { couple interactions can } \\
\text { be used to identify } \\
\text { affective states which are } \\
\text { relevant to the partners' } \\
\text { communication }\end{array}$ \\
\hline $\begin{array}{l}\text { Pietrzak et al. } \\
\text { (2017) }\end{array}$ & $\begin{array}{l}\text { Qualitative } \\
\text { research }\end{array}$ & $\begin{array}{l}\text { Fostering emotional } \\
\text { regulation, } \\
\text { multifaceted empathy, } \\
\text { and conflict resolution } \\
\text { via emotional } \\
\text { activation therapy }\end{array}$ & $\begin{array}{l}\text { Two } \\
\text { couples } \\
\text { diagnosed } \\
\text { with } \\
\text { borderline } \\
\text { personality } \\
\text { disorder }\end{array}$ & $20 \mathrm{~h}$ & $\begin{array}{l}\text { Imitation of a personal } \\
\text { choreography, } \\
\text { movement } \\
\text { synchronization, and } \\
\text { collaboration in resolving } \\
\text { incidents of } \\
\text { nonsynchronization of } \\
\text { movement }\end{array}$ & $\begin{array}{l}\text { Pre- to post-test } \\
\text { change scores }\end{array}$ & $\begin{array}{l}\text { The couples reported } \\
\text { greater relationship } \\
\text { satisfaction, a more } \\
\text { securely attached } \\
\text { relationship, and } \\
\text { increases in empathy in } \\
\text { the relationship }\end{array}$ \\
\hline
\end{tabular}


TABLE 2 | Continued

\begin{tabular}{|c|c|c|c|c|c|c|c|}
\hline References $^{a}$ & $\begin{array}{l}\text { Study } \\
\text { design }\end{array}$ & Objective & Sample & $\begin{array}{l}\text { Intervention } \\
\text { length }\end{array}$ & Intervention elements & Evaluation tools & Results/conclusions \\
\hline Polo (2010) & $\begin{array}{l}\text { Phenomeno } \\
\text {-logical } \\
\text { research } \\
\text { methods }\end{array}$ & $\begin{array}{l}\text { Gaining an in-depth } \\
\text { understanding of the } \\
\text { various dimensions of } \\
\text { relationship } \\
\text { experienced by } \\
\text { Argentine tango } \\
\text { dancers }\end{array}$ & $\begin{array}{l}\text { Three male } \\
\text { tango } \\
\text { "leaders" } \\
\text { and three } \\
\text { female } \\
\text { "followers" } \\
\text { of various } \\
\text { experience } \\
\text { levels } \\
\text { (dance } \\
\text { partners } \\
\text { only) }\end{array}$ & $\begin{array}{l}\text { Single 2-h } \\
\text { session }\end{array}$ & Dancing tango socially & $\begin{array}{l}\text { (1) The } \\
\text { participants } \\
\text { dancing tango } \\
\text { were recorded; (2) } \\
\text { they were } \\
\text { interviewed } \\
\text { separately using a } \\
\text { customized video } \\
\text { for each as a } \\
\text { prompt discussion } \\
\text { of the dance } \\
\text { relationships }\end{array}$ & $\begin{array}{l}\text { DMT could be used in } \\
\text { tandem with tango by } \\
\text { exploring effort and effort } \\
\text { qualities that best } \\
\text { support the role of the } \\
\text { leader and the role of the } \\
\text { follower }\end{array}$ \\
\hline $\begin{array}{l}\text { Wagner and } \\
\text { Hurst (2018) }\end{array}$ & $\begin{array}{l}\text { Theoretical } \\
\text { model and } \\
\text { case example }\end{array}$ & $\begin{array}{l}\text { Development of a } \\
\text { theoretical framework } \\
\text { for DMT with romantic } \\
\text { partners }\end{array}$ & One couple & - & $\begin{array}{l}\text { Palm-to-Palm Work as } \\
\text { the Dance of the Internal } \\
\text { Family System (e.g., } \\
\text { experiment with degrees } \\
\text { of pressure, exploring } \\
\text { leading and following) }\end{array}$ & - & $\begin{array}{l}\text { Dance/movement } \\
\text { therapists can recognize } \\
\text { and process unresolved } \\
\text { development dances that } \\
\text { need re-patterning }\end{array}$ \\
\hline
\end{tabular}

aln all studies, the intervention was performed by the researchers.

In this proposed study, the efficacy of DMT-C with ASD will be examined by using an RCT model comparing three groups of couples: two intervention groups [DMT-C, verbal therapy (VT), and a delayed DMT-C group (DG)]. The comparison of the intervention protocol will help determine the unique contribution of each treatment modality to improvements in the subjects' capacity for communication, intimacy, and reflective functioning, whereas the comparison of each modality with the DG is aimed to verify improvement beyond natural maturation.

Moreover, literature on music therapy and ASD is continuously growing (Thompson and Elefant, 2019; Epstein et al., 2020; Nielsen and Holck, 2020), and the benefits of DMT may partly be due to the therapeutic effects of music by itself. Perhaps future research could incorporate an experimental design in which DMT-C could be compared with a control group exposed to the same music but without the dance element to determine the effect of dance on its own. Additionally, we would propose DMT as an appropriate intervention designed to raise emotional awareness and social skills and believe that a suitable manualized intervention is likely to be helpful in developing programs for community interventions tailored to the needs of people diagnosed with ASD. By working on the quality of intersubjective communication through DMT, we expect to see an improvement of the quality of the couples' relationship, of the duration of the relationship, and in the partners' satisfaction with each other.

\section{DISCUSSION}

Drawing on a number of empirical studies, the aim of this review was to create a comprehensive picture of current research addressing the issues of couple relationships where one partner is diagnosed with ASD in order to understand the potential contribution of DMT in these cases. The survey suggests that
DMT-C can contribute to synchronization, adjustment, and familiarity between the partners and that this form of support may be beneficial in terms of the relationship and help the partners cope with the difficulties entailed in ASD.

Both DMT interventions with adults diagnosed with ASD and DMT-C were found to be a valuable mode of supporting interpersonal communication and empathy through movement experiences and may thus be constructively combined to help adults with ASD in engaging with and maintaining intimate relations. The review shows that bodily mirroring has been extensively referenced in the context of working with clients diagnosed with ASD (Baron-Cohen, 2004; McGarry and Russo, 2011; Koehne et al., 2016b; Feniger-Schaal et al., 2018) in order to support social skills and emotional awareness.

As described previously, this is also precisely what is practiced in DMT-C when there is a disruption or difficulty in using these mechanisms. The ability to identify with one's emotion, alongside the establishment of a distinction between the needs and feelings of each one of the partners (Siegel, 2012, p. 6), is the basis for intimate relations, symbolizing the extent of the couple's closeness and the freedom to express the self fully in the relationship while enabling the partner to possess a separate self (Lerner, 2017).

This review emphasizes that heightened emotional awareness is achieved through the transition from awareness of bodily experiences to their verbalization within the DMT session. The articles reviewed emphasize that DMT, which draws attention to the bodily experience and sensations, is helpful for individuals who find it difficult to reflect verbally on their emotions, thoughts, and feelings (Shuper Engelhard, 2019e). It is important to understand the uniqueness of movement for the processing of embodied knowledge as described by Koch et al. (2015, p. 2): "the mind is not hidden but directly expressed in other persons' embodied actions' from the earliest days of infancy.” 
This understanding, alongside the translation of physical and emotional experiences into verbal discourse in order to improve and support intimate relationships, will aid in the development of intervention programs for adults diagnosed with ASD.

\section{CONCLUSIONS}

The benefits of integrating movement into couple therapy and into emotional therapy for individuals with ASD are gaining more recognition and scope in research and clinical practice. This review indicates that DMT may contribute to the wellbeing and quality of day-to-day lives of adults with ASD. The ability to identify and express bodily sensations and to relate them to emotions may assist the partners in forming and maintaining adult intimate and sexual encounters, identifying and communicating needs, and feeling understood and loved by another. Moreover, understanding the role of the body

\section{REFERENCES}

Anderberg, E., Cox, J. C., Neeley Tass, E. S., Erekson, D. M., Gabrielsen, T. P., Warren, J. S., et al. (2017). Sticking with it: psychotherapy outcomes for adults with autism spectrum disorder in a university counseling center setting. Autism ResearchRes., 10(12), 2048-2055. doi: 10.1002/aur.1843

Baron-Cohen, S. (2004). The cognitive neuroscience of autism. J. Neurol. Neurosurg. Psychiatry 75, 945-948. doi: 10.1136/jnnp.2003.018713

Baron-Cohen, S. (2010). Empathizing, systemizing, and the extreme male brain theory of autism. Progress in. Brain ResearchRes., 186, 167-175. doi: 10.1016/B978-0-444-53630-3.00011-7

Baron-Cohen, S., and Wheelwright, S. (2004). The empathy quotient: an investigation of adults with Asperger syndrome or high functioning autism, and normal sex differences. Journal of Autism and Dev.elopmental DisordersDisord., 34(2), 163-175. doi: 10.1023/B:JADD.0000022607.19833.00

Behrends, A., Müller, S., and Dziobek, I. (2012). Moving in and out of synchrony: A a concept for a new intervention fostering empathy through interactional movement and dance. The Arts in Psychotherapy, 39(2), 107-116. doi: 10.1016/j.aip.2012.02.003

Bird, G., and Viding, E. (2014). The self to other model of empathy: providing a new framework for understanding empathy impairments in psychopathy, autism, and alexithymia. Neuroscience and. Biobehavioral Biobehav. ReviewsRev., 47, 520-532. doi: 10.1016/j.neubiorev.2014. 09.021

Brezis, R. S., Noy, L., Alony, T., Gotlieb, R., Cohen, R., Golland, Y., et al. (2017). Patterns of joint improvisation in adults with autism spectrum disorder. Frontiers in. Psychology,. 8, 1790. doi: 10.3389/fpsyg.2017.01790

Cheak-Zamora, N. C., Teti, M., Maurer-Batjer, A., O'Connor, K. V., and Randolph, J. K. (2019). Sexual and relationship interest, knowledge, and experiences among adolescents and young adults with autism spectrum disorder. Archives of. Sexual BehaviorBehav., 48(8), 2605-2615. doi: 10.1007/s10508-019-1445-2

Cohen, J. (1988). Statistical Power Analysis for the Behavioral Sciences, 2nd Edn. Hillsdale, NJ: Erlbaum.

Cunningham, J. (2014). Potential benefits of dance movement psychotherapy with couples experiencing infertility. Body, Movement and. Dance in Psychotherapy, 9(4), 237-252. [Taylor and Francis Online], [Google Scholar] doi: 10.1080/17432979.2014.946969

DeBoer, D. P. (2006). The Exploratory Use of Partner Dancing as an Adjunct to Couples Counseling. University of Minnesota.

Deguchi, N., and Asakura, T. (2018). Qualitative study of wives of husbands with autism spectrum disorder: subjective experience of wives from marriage to marital crisis. Psychology, 9: 14. doi: 10.4236/psych.2018. 91002 and its movement in therapy when emotional discourse is limited can help formulate unique intervention programs for adults diagnosed with ASD as DMT can assist in improving communication and intimacy which may later lead to a higher degree of autonomy when one of the partners is diagnosed with ASD. By offering this literature review, we hope to make a contribution to a better quality of life for adults with ASD by helping them to overcome isolation and engage in meaningful and enjoyable familial and social interactions. The implications of the review will hopefully encourage researchers to take these insights further in future research.

\section{AUTHOR CONTRIBUTIONS}

ES and MV have contributed equally to the article and approved the submitted version. Both authors have contributed to the main body of text and to its main ideas.

DeJesus, B. M., Oliveira, R. C., de Carvalho, F. O., de Jesus Mari, J., Arida, R. M., and Teixeira-Machado, L. (2020). Dance promotes positive benefits for negative symptoms in autism spectrum disorder (ASD): A a systematic review. Complementary Complem. Therapies in. MedicineMed., 49, :102299. doi: 10.1016/j.ctim.2020.102299

Delafield-Butt, J. T., Zeedyk, M. S., Harder, S., Væver, M. S., and Caldwell, P. (2020). Making meaning together: embodied narratives in a case of severe autism. Psychopathology, 1-1453, 60-73 doi: 10.1159/000506648

Dembosky, J. W. (2020). The Everyday Challenges Faced by Young Adults with Autism and Their Parents, (Doctoral dissertation, Indiana University of Pennsylvania).

Devereaux, C. (2012). "Moving into relationship: Dance/movement therapy with children with autism.," In in: eds. L. Gallo-Lopez and L. Rubin (Eds.), Play Based Interventions for Children and Adolescents With Autism Spectrum Disorders (pp. 333-351). New York, NY: Routledge), 333-351.

Eberhard-Kaechele, M. (2009). "Von der Ko-Regulation zur Selbstregulation: Spiegelungsphänomene in der Tanz-und Ausdruckstherapie (From coregulation to self-regulation. Mirroring in Dance and Expressive Therapy)," in Körper-Gefühl-Denken. Körperpsychotherapie und Selbstregulation (BodyEmotion-Thinking. Bodypsychotherapy and Self-Regulation), 251-264.

Eberhard-Kaechele, M. (2012). "Memory, metaphor, and mirroring in movement therapy with trauma patients," in Body Memory, Metaphor and Movement, 267-287.

Edwards, J. (2015). Exploring sensory sensitivities and relationships during group dance movement psychotherapy for adults with autism. Body, Movement and Dance in Psychotherapy, 10(1), 5-20. doi: 10.1080/17432979.2014.978894

Eigsti, I. M., de Marchena, A. B., Schuh, J. M., and Kelley, E. (2011). Language acquisition in autism spectrum disorders: A a developmental review. Research in. Autism Spectrum Disorders,. 5(2), 681-691. doi: 10.1016/j.rasd.2010. 09.001

Epstein, S., Elefant, C., and Thompson, G. (2020). Music therapists' perceptions of the therapeutic potentials using music when working with verbal children on the autism spectrum: a qualitative analysis. J Music Therapy 57, 66-90. doi: 10.1093/jmt/thz017

Feniger-Schaal, R., Hart, Y., Lotan, N., Koren-Karie, N., and Noy, L. (2018). The body speaks: using the mirror game to link attachment and non-verbal behavior. Front. Psychol. 9:1560. doi: 10.3389/fpsyg.2018.01560

Fitzpatrick, P., Diorio, R., Richardson, M. J., and Schmidt, R. C. (2013). Dynamical methods for evaluating the time-dependent unfolding of social coordination in children with autism. Front. Integr. Neurosci. 7:21. doi: $10.3389 /$ fnint.2013.00021

Fletcher-Watson, S., and Bird, G. (2020). Autism and empathy: what are the real links? Autism. 24, 3-6. doi: 10.1177/1362361319883506 
Fuchs, T., and Koch, S. C. (2014). Embodied affectivity: on moving and being moved. Front. Psychol. 5:508. doi: 10.3389/fpsyg.2014.00508

Hawkes, L. (2003). The tango of therapy: a dancing group. Trans. Anal. J. 33, 288-301. doi: 10.1177/036215370303300404

Hildebrandt, M. K., Koch, S. C., and Fuchs, T. (2016). "We Dance and Find Each Other" 1: effects of dance/movement therapy on negative symptoms in autism spectrum disorder. Behav. Sci. 6:24. doi: 10.3390/bs6040024

Kier, S. (2011). Is dance/movement therapy relevant to the process of achieving a healthy sexuality? Am. J. Dance Therapy 33:42. doi: 10.1007/s10465-011-9103-9

Kim, S. Y., Kang, H. W., Chung, Y. C., and Park, S. (2013). Empirical application of empathy enhancing program based on movement concept for married couples in conflict. J. Exerc. Rehabil. 9, 426-431. doi: 10.12965/jer.130056

Koch, S. C., Gaida, J., Kortum, R., Bodingbauer, B., and Manders, E. (2016). Body image in autism: an exploratory study on the effects of dance movement therapy. Autism Open Access 6, 1-7. doi: 10.4172/2165-7890.1000175

Koch, S. C., Mehl, L., Sobanski, E., Sieber, M., and Fuchs, T. (2015). Fixing the mirrors: a feasibility study of the effects of dance movement therapy on young adults with autism spectrum disorder. Autism 19, 338-350. doi: 10.1177/1362361314522353

Koegel, R. L., Vernon, T. W., and Koegel, L. K. (2009). Improving social initiations in young children with autism using reinforcers with embedded social interactions. J. Autism Dev. Disord. 39, 1240-1251. doi: 10.1007/s10803-009-0732-5

Koehne, S., Behrends, A., Fairhurst, M. T., and Dziobek, I. (2016a). Fostering social cognition through an imitation-and synchronization-based dance/movement intervention in adults with autism spectrum disorder: a controlled proofof-concept study. Psychotherapy Psychosom. 85, 27-35. doi: 10.1159/000 441111

Koehne, S., Hatri, A., Cacioppo, J. T., and Dziobek, I. (2016b). Perceived interpersonal synchrony increases empathy: insights from autism spectrum disorder. Cognition 146, 8-15. doi: 10.1016/j.cognition.2015. 09.007

Lacson, F. C. (2020). Embodied attunement: a dance/movement therapy approach to working with couples. Body Mov. Dance Psychotherapy 15, 4-19. doi: 10.1080/17432979.2019.1699859

Le, B., Dove, N. L., Agnew, C. R., Korn, M. S., and Mutso, A. A. (2010). Predicting nonmarital romantic relationship dissolution: a meta-analytic synthesis. Pers. Relationsh. 17, 377-390. doi: 10.1111/j.1475-6811.2010.01285.x

Lerner, H. (2017). The Dance of Intimacy. Pune: Mehta Publishing House.

Mastrominico, A., Fuchs, T., Manders, E., Steffinger, L., Hirjak, D., Sieber, M., et al. (2018). Effects of dance movement therapy on adult patients with autism spectrum disorder: a randomized controlled trial. Behav. Sci. 8:61. doi: 10.3390/bs8070061

Mateos-Moreno, D., and Atencia-Doña, L. (2013). Effect of a combined dance/movement and music therapy on young adults diagnosed with severe autism. Arts Psychotherapy 40, 465-472. doi: 10.1016/j.aip.2013.09.004

McGarry, L. M., and Russo, F. A. (2011). Mirroring in dance/movement therapy: potential mechanisms behind empathy enhancement. Arts in Psychotherapy 38, 178-184. doi: 10.1016/j.aip.2011.04.005

Naber, F. B., Bakermans-Kranenburg, M. J., Van IJzendoorn, M. H., Dietz, C., Van Daalen, E., Swinkels, S. H., et al. (2008). Joint attention development in toddlers with autism. Eur. Child Adolesc. Psychiatry 17, 143-152. doi: 10.1007/s00787-007-0648-6

Naoko, D., Takashi, A., and Tomoko, O. (2020). Development and preliminary validation of the couples' stigma scale to assess self-stigma among the partners of persons with autism spectrum disorder in Japan. Int. J. Environ. Res. Public Health 17:3533. doi: 10.3390/ijerph17103533

Nielsen, J. B., and Holck, U. (2020). Synchronicity in improvisational music therapy-Developing an intersubjective field with a child with autism spectrum disorder. Nordic J. Music Therapy 29, 112-131. doi: 10.1080/08098131.2019.1680571

Orsmond, G. I., Krauss, M. W., and Seltzer, M. M. (2004). Peer relationships and social and recreational activities among adolescents and adults with autism. $J$. Autism Dev. Disord. 34, 245-256. doi: 10.1023/B:JADD.0000029547.96610.df

Patterson, J., Gardner, B. C., Burr, B. K., Hubler, D. S., and Roberts, K. M. (2012). Nonverbal behavioral indicators of negative affect in couple interaction. Contemp. Fam. Therapy 34, 11-28. doi: 10.1007/s10591-011-9170-6
Pietrzak, T., Hauke, G., and Lohr, G., (2017). "Connecting couples intervention: Improving couples' empathy and emotional regulation using embodied empathy," in ed. G. Hauke, European Psychotherapy 2016/2017: Embodiment in Psychotherapy (Milton Keynes: Books on Demand), 66-98.

Polo, G. (2010). The Space Between Us: The Experience of Relationship in the Argentine Tango. Creative Arts Therapies Theses.

PRISMA (2015). Transparent Reporting of Systematic Reviews and MetaAnalyses. Retrieved from: March 9, 2018 from http://www.prisma-statement. org/ (accessed March 9, 2018).

Roy, M., and Dillo, W. (2017). Asperger syndrome and partnership. J. Autism 4:1. doi: 10.7243/2054-992X-4-1

Sala, G., Hooley, M., and Stokes, M. A. (2020). Romantic intimacy in autism: a qualitative analysis. J. Autism Dev. Disord. 50, 4133-4147. doi: 10.1007/s10803-020-04377-8

Schöttle, D., Briken, P., Tüscher, O., and Turner, D. (2017). Sexuality in autism: hypersexual and paraphilic behavior in women and men with high-functioning autism spectrum disorder. Dialog. Clin. Neurosci. 19, 381. doi: 10.31887/DCNS.2017.19.4/dschoettle

Seltzer, M. M., Shattuck, P., Abbeduto, L., and Greenberg, J. S. (2004). Trajectory of Development in Adolescents and Adults with Autism. Mental Retard. Dev. Disabil. Res. Rev. 10, 234-247. doi: 10.1002/mrdd.20038

Shuper Engelhard, E. (2018). Being together in time: body synchrony in couples' psychotherapy. Art Psychotherapy 60, 41-47. doi: 10.1016/j.aip.2018.06.003

Shuper Engelhard, E. (2019a). Clinical intervention using dance-movement psychotherapy for couples-qualitative research and clinical implications. Body Mov. Dance Psychotherapy. 14, 128-142. doi: 10.1080/17432979.2019.1618395

Shuper Engelhard, E. (2019b). Dancing to projective identification in couples therapy - qualitative research and practical application. Arts Psychotherapy. 67:101614. doi: 10.1016/j.aip.2019.101614

Shuper Engelhard, E. (2019c). Embodying the couple relationship: kinesthetic empathy and somatic mirroring in couples therapy. J. Couple Relationsh. Therapy. 18, 126-147. doi: 10.1080/15332691.2018.1481801

Shuper Engelhard, E. (2019d). Ghosts in the bedroom - embodiment wishes in couple sexuality: qualitative research and practical application. Am. J. Dance Therapy 41, 302-317. doi: 10.1007/s10465-019-09302-w

Shuper Engelhard, E. (2019e). Review of comprehensive research in dance-movement psychotherapy for couples (DMP-C) and systematic treatment guidelines. Body Mov. Dance Psychotherapy 14, 204-217. doi: 10.1080/17432979.2019.1653373

Shuper Engelhard, E., and Vulcan, M. (2018). Introducing movement into couple therapy: clients' expectations and perceptions. Contemp. Fam. Therapy. 41, 102-114. doi: 10.1007/s10591-018-9474-x

Siegel, D. J. (2012). Pocket Guide to Interpersonal Neurobiology: An Integrative Handbook of the Mind. New York, NY: Norton.

Strunz, S., Schermuck, C., Ballerstein, S., Ahlers, C. J., Dziobek, I., and Roepke, S. (2017). Romantic relationships and relationship satisfaction among adults with asperger syndrome and high-functioning autism. J. Clin. Psychol. 73, 113-125. doi: 10.1002/jclp.22319

Takahashi, H., Matsushima, K., and Kato, T. (2019). The effectiveness of dance/movement therapy interventions for autism spectrum disorder: a systematic review. Am. J. Dance Therapy 41, 1-20. doi: 10.1007/s10465-019-09296-5

Tani, M., Kanai, C., Ota, H., Yamada, T., Watanabe, H., Yokoi, H., et al. (2012). Mental and behavioral symptoms of person's with asperger's syndrome: relationships with social isolation and handicaps. Res. Autism Spectrum Disord. 6, 907-912. doi: 10.1016/j.rasd.2011.12.004

Thompson, G. A., and Elefant, C. (2019). "But I want to talk to you!" Perspectives on music therapy practice with highly verbal children on the autism spectrum. Nordic J. Music Ther. 28, 347-359. doi: 10.1080/08098131.2019.1605616

Vulcan, M. (2016). "I'm a translating body": Therapists' experiences working with children diagnosed with autism spectrum disorder. J. Psychotherapy Integr. 26, 326. doi: 10.1037/int0000026

Vulcan, M., and Shuper Engelhard, E. (2019). Body and movement in couple intake: the intake phase. Arts Psychotherapy 64, 49-58. doi: 10.1016/j.aip.2019.02.001

Wadsworth, J., and Hackett, S. (2014). Dance movement psychotherapy with an adult with autistic spectrum disorder: an observational single-case study. 
Body Mov. Dance Psychotherapy 9, 59-73. doi: 10.1080/17432979.2014. 893259

Wagner, D., and Hurst, S. M. (2018). Couples Dance/Movement Therapy: Bringing a Theoretical Framework into Practice. Am. J. Dance Therapy 40, 18-43. doi: 10.1007/s10465-0189271-y

Zapata-Fonseca, L., Dotov, D., Fossion, R., Froese, T., Schilbach, L., Vogeley, K., et al. (2019). Multi-scale coordination of distinctive movement patterns during embodied interaction between adults with high-functioning autism and neurotypicals. Front. Psychol. 9:2760doi: 10.3389/fpsyg.2018. 02760
Conflict of Interest: The authors declare that the research was conducted in the absence of any commercial or financial relationships that could be construed as a potential conflict of interest.

Copyright (๑) 2021 Shuper Engelhard and Vulcan. This is an open-access article distributed under the terms of the Creative Commons Attribution License (CC BY). The use, distribution or reproduction in other forums is permitted, provided the original author(s) and the copyright owner(s) are credited and that the original publication in this journal is cited, in accordance with accepted academic practice. No use, distribution or reproduction is permitted which does not comply with these terms. 